VOLUMINA JURASSICA, 2021, XIX: 95-108

DOI: 10.7306/NJ.19.4

\title{
New records of Tmaegoceras lacordarii (Michelin, 1835) from the Lower Jurassic Arietenkalk Formation of SW Germany and its systematic relationships
}

\author{
Günter SCHWEIGERT ${ }^{1}$, Armin SCHERZINGER $^{2}$, Stefan GRÄBENSTEIN ${ }^{3}$
}

Key words: ammonites, systematics, Pseudotropitinae, palaeobiogeography, Sinemurian.

\begin{abstract}
New material of the enigmatic cosmopolitan ammonite genus Tmaegoceras Hyatt, 1889 is reported from the upper Lower Sinemurian (Bucklandi Zone, 'cf. pinguis' Biohorizon) of SW Germany. It is better preserved than previously described material. All specimens are assigned to Tmaegoceras lacordarii (Michelin, 1835), an almost forgotten subjective senior synonym of Tmaegoceras crassiceps Pompeckj, 1901. The presence of an extreme rursiradiate ribbing style in some specimens allows a better understanding of this genus and provides a hint for its systematic affiliation. This diagnostic ribbing style is shared with some extremely rare Alpine taxa such as $A m$ monites salinarius Hauer, 1846 and "Arietites" subsalinarius Wähner, 1891. Tmaegoceras is included here in Pseudotropitinae Donovan, 1973. Pseudotropitinae are possibly an early offshoot of Arietitidae indigenous of the Panthalassa Realm that occasionally spread into the Tethys and its adjacent shelves. A phyletic relationship with Late Triassic Tropitidae Mojsisovics, 1875, however, cannot be excluded either.
\end{abstract}

\section{INTRODUCTION}

The Lower Jurassic strata of southern Germany and their rich fossil content have been studied from the very beginning of palaeontology. In their lower part, a formation of dark limestones and marls, the Arietenkalk Formation, which is of Sinemurian age, forms a first Jurassic escarpment rising above the wide plains covered with Pleistocene loess deposits (Bloos et al., 2006). In former times, the limestone of the Arietenkalk Formation was exploited in numerous small quarries all over the country; however, these quarries are nowadays abandoned and no longer accessible. The limestone beds are often very rich in fossils, such as the rock-forming oyster Gryphaea arcuata Lamarck, 1801, and are especially famous for mass occurrences of large to giant- sized arietitid ammonites (e.g., Metophioceras, Coroniceras, Arietites, Paracoroniceras, Asteroceras). The bulk of the ammonite fauna of this formation was described by Quenstedt $(1856,1882-1883)$, but many of his taxa lacked detailed stratigraphical information. Walliser (1956a, b) provided lithological correlations and biostratigraphical interpretations of several sections of the Arietenkalk Formation in the central and western part of the country. Walliser's study was long thought to be exhaustive (Urlichs, 1977), but the biostratigraphical resolution provided is rather low in comparison with neighbouring areas, where successions of biohorizons have been introduced (e.g., Corna, 1987; Guérin-Franiatte, 1994; Corna et al., 1997; Page, 2003, 2010). Establishing a biostratigraphical succession of biohorizons for the Sinemurian of southern Germany is in progress

\footnotetext{
${ }^{1}$ Staatliches Museum für Naturkunde, Rosenstein 1, 70191 Stuttgart, Germany; guenter.schweigert@smns-bw.de.

${ }^{2}$ Maurenstraße 26, 78194 Immendingen-Hattingen, Germany; armin.scherzinger@t-online.de.

${ }^{3}$ Landhausstraße 20, 72411 Bodelshausen, Germany; g.g.landhaus@t-online.de.
} 
(Scherzinger et al., 2020). The knowledge about the exact position of age-diagnostic ammonites in defined sections is crucial for establishing a high-resolution biostratigraphy and for correlation with other areas. In this context, one of the most enigmatic ammonite taxa ever recorded from the Arietenkalk Formation is the genus Tmaegoceras Hyatt, 1889. From southern Germany, Tmaegoceras was reported for the first time by Pompeckj (1901), who introduced a new species, Tmaegoceras crassiceps, based on a single, incomplete and small-sized specimen. More recently, two further specimens assigned to Tmaegoceras crassiceps have been published (Gebhard, Schlatter, 1977). In the meantime, more and better preserved Tmaegoceras material has appeared. This new material is studied und discussed here.

\section{BIOGEOGRAPHIC DISTRIBUTION OF TMAEGOCERAS}

Originally described from the western Tethys (Northern Calcareous Alps, Central Europe), the genus Tmaegoceras Hyatt, 1889 has an extremely wide, apparently almost cosmopolitan palaeogeographic distribution. It is recorded from the Northern Calcareous Alps of Austria (Hauer, 1856; Böhm et al., 1999), Hungary (Koch, 1909a, b; Fülöp, 1976; Géczy, Meister, 2007); the Italian Apennines (Bonarelli, 1899; Venturi et al., 2010; Venturi, Nannarone, 2002), Morocco (Mouterde et al., 1986; Dommergues, Meister, 2017), southern Spain (Braga et al., 1984); southern Germany (Pompeckj, 1901; Schlegelmilch, 1976; Gebhard, Schlatter, 1977; Schweigert, 2018; this paper), southern England (Gebhard, Schlatter, 1977), eastern France (Michelin, 1835; Guérin-Franiatte, 1990), western North America (Taylor, 1998; Taylor et al., 2001; Hou, 2014; Taylor, Guex, 2021), and New Zealand (Stevens, 2004). Since we consider the poorly known genus Longziceras Wang and He, 1981 (type species: Longziceras longziense Wang and He 1981, p. 327, pl. 3, figs. 1-5) as a subjective junior synonym of Tmaegoceras, the palaeogeographic distribution even expands to present-day Tibet.

Small nuclei undoubtedly representing juvenile Tmaegoceras spp. were illustrated as ,Arietites cfr. ligusticus Cocchi" by Gugenberger (1936, pl. 1, fig. 20) from presumed Sinemurian strata of Sicily and subsequently by Kovács (1942, pl. 3, fig. 5) from the Sinemurian of Hungary.

\section{MATERIAL AND METHODS}

Three of the new specimens of Tmaegoceras presented herein were collected by the late Norbert Wannenmacher from a well-defined bed ('Schneckenfels') of the Arietenkalk Formation in temporary outcrops in the foreland of the western Swabian Alb (Figs. 1, 2). The samples were taken from the exposed sections and later prepared mechanically using pneumatic tools. Soon after his unexpected death in 2020, these specimens were donated to the palaeontological collection of the Stuttgart Natural History Museum. To enhance the lateral ribbing sculpture, the specimens were coated with ammonium chloride and photographed under illumination at an oblique angle. Further specimens from private collections (Uwe Fidder, Thorsten Ott) were included in this study as well to get an idea about intraspecific variability. Two juvenile Tmaegoceras specimens, one from the 'Schneckenfels' of Balingen-Engstlatt (coll. T. Ott) and another one from the same bed at Bodelshausen (coll. S. Gräbenstein), remain unprepared. For comparison, we reviewed the historical type specimens of supposed ancestral taxa housed in the collections of the Natural History Museum of Vienna and the Geologische Bundesanstalt of Vienna, respectively.

Abbreviations. GBA $=$ Geologische Bundesanstalt, Vienna, Austria; NHMW = Naturhistorisches Museum Wien, Vienna, Austria; SMNS = Staatliches Museum für Naturkunde Stuttgart, Germany; $\mathrm{d}_{\max }=$ maximum diameter; $w h=$ whorl height; ww = whorl width; uw = umbilical width.

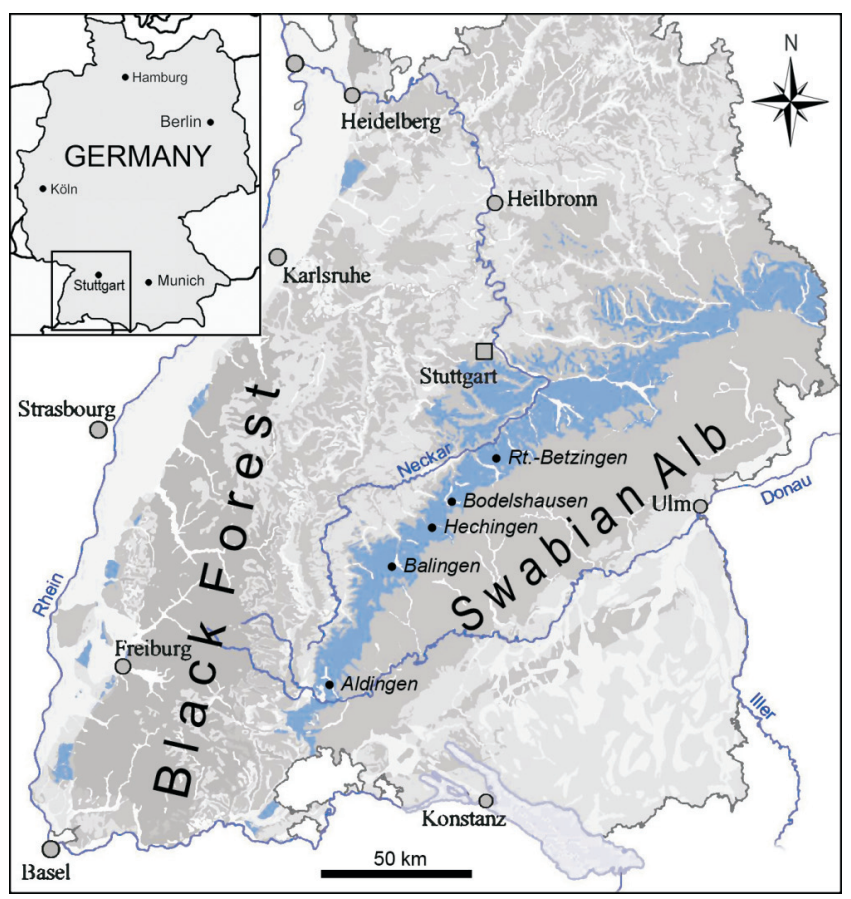

Fig. 1. Locality map showing the presently known occurrences of Tmaegoceras lacordarii (Michelin, 1835) in the Swabian Lower Jurassic 


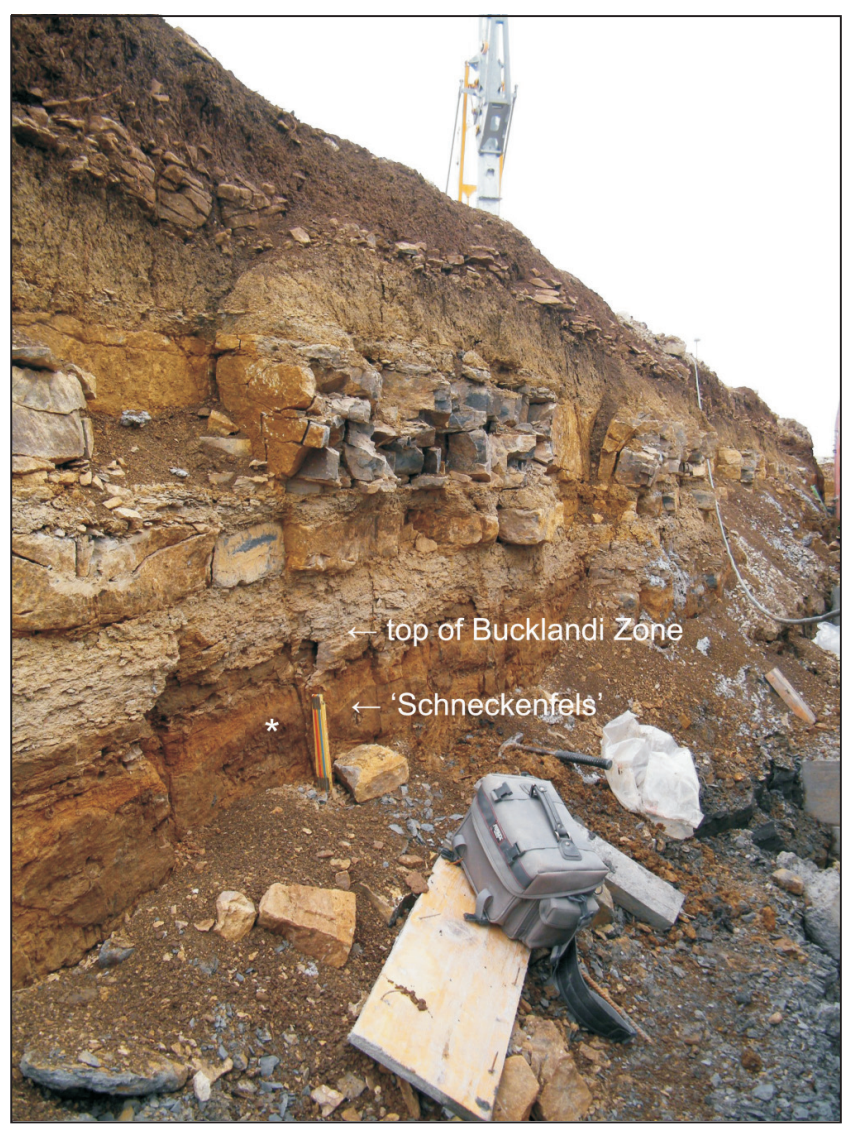

Fig. 2. Temporary exposure of the middle part of the Arietenkalk Formation in the vicinity of Hechingen

The asterisk marks the principal horizon of Tmaegoceras lacordarii (Michelin, 1835 ) in the 'Schneckenfels' bed. Photograph taken by N. Wannenmacher in 2011

\section{SYSTEMATIC PALAEONTOLOGY}

\section{Order Ammonitida Fischer, 1882}

Superfamily Psiloceratoidea Hyatt, 1867

Family Arietitidae Hyatt, 1875

\section{Subfamily Pseudotropitinae Donovan \\ in Donovan and Forsey, 1973}

Genus Tmaegoceras Hyatt, 1889

(syn.: Longziceras Wang and He, 1981)

Type species. Ammonites latesulcatus Hauer, 1856, subsequent designation by Pompeckj (1901).
Included species. Ammonites lacordarii Michelin, 1835; Ammonites salinarius Hauer, 1846; Ammonites latesulcatus Hauer, 1856; Tmaegoceras paronai Bonarelli, 1899; Tmaegoceras crassiceps Pompeckj, 1901; Longziceras longziense Wang, He, 1981; Tmaegoceras nudaries Taylor, 1998. Tmaegoceras obesum Hou, 2014 [nom. corr. pro Tmaegoceras obesus in Hou, 2014] was introduced in an unpublished master thesis and thus does not fully satisfy the criteria of validity demanded by the ICZN (1999, Art. 8.6).

Excluded species. As already pointed out by Gebhard, Schlatter (1977), Arietites laevis Stur in Geyer, 1886, originally included in Tmaegoceras, subsequently became the type species of Tmaegophioceras Spath, 1925. Bonarelli (1899) considered Ammonites helli Schafhäutl, 1851 (Schafhäutl, 1851: 107, pl. 15, fig. 21) as another species of Tmaegoceras, but he was obviously unaware about the previous re-interpretation of Ammonites helli as a Late Triassic Tropites by Mojsisovics (1893). The holotype of Ammonites helli was re-illustrated by Reynès (1879), who was unaware of its Triassic age, either. Recently, Géczy, Meister (2007) still listed that taxon under Tmaegoceras. The strongly prorsiradiate ribbing style of Ammonites helli covering the entire flanks of the body chamber clearly contradicts this generic assignment.

The dwarfish Ammonites dorsosulcus Quenstedt, 1883 from the Upper Hettangian of southwestern Germany has been repeatedly included in Tmaegoceras as well, at least tentatively (Pompeckj, 1901; Schindewolf, 1962; Schlegelmilch, 1976; Gebhard, Schlatter, 1977; Taylor, 1998), whereas other authors clearly rejected such an assignment (Koch 1909a, b) or interpreted the presence of the dorsal sulcus as a case of pathology, respectively (Hengsbach, 1986). The very small nuclei on which Ammonites dorsosulcus are based do not show the typical characters of Tmaegoceras (see discussion in Gebhard, Schlatter 1977), and the taxon Ammonites dorsosulcus must be considered as a nomen dubium. Most likely, these undeterminable nuclei represent juvenile schlotheimiids. This dubious Hettangian material misled Pompeckj (1901), who erroneously assumed that the ventral sulcus of Tmaegoceras appears prior to the development of keel during ontogeny.

Discussion. We interpret the fading of the ventral sulcus on the body chamber of Longziceras Wang and He, 1981 as an adult character, which is similarly known from the invalid 'Tmaegoceras obesum Hou, 2014' of British Columbia. The relatively small size of Longziceras either points to a microconch or to a small-sized species. Sexual dimorphism, still neglected even in the most recent ammonite classification (Howarth, 2013), has not been demonstrated yet in Tmaegoceras, but it is well present in Jurassic ammonites from the stratigraphically oldest ammonite genus, Psiloceras Hyatt, 1867, onwards (Guex, 1981, and own observation). 
Among the material illustrated by Taylor, Guex (2021), relatively small and evolute specimens could be microconchs, whereas the largest specimens reached diameters of over $100 \mathrm{~mm}$ and most likely represent macroconchs.

\section{Tmaegoceras lacordarii (Michelin, 1835)}

$$
\text { Fig. 3A-H }
$$

*1835. A[mmonites]. Lacordarii [sic]. Michelin, pl. 67.

1901. Tmaegoceras crassiceps Pompeckj, p. 163, fig. 1.

1902. Tmaegoceras crassiceps Pompeckj. Crick, p. 127.

1909a. Tmaegoceras Lacordairei Michelin sp. Koch, p. 277, figs. 1-3.

1909b. Tmaegoceras Lacordairei Michelin sp. Koch, p. 310, figs. 1-3.

1976. Tmaegoceras crassiceps Pompeckj. Fülöp, pl. 16, fig. 1.

1976. Tmaegoceras crassiceps Pomp. 1901. Schlegelmilch, p. 45 , pl. 10 , fig. 6 .

1977. Tmaegoceras crassiceps Pompeckj. Gebhard, Schlatter, pp. 2, 3, pl. 1, figs. 1-3.

?1984. Tmaegoceras cf. crassiceps Pompeckj. Braga et al., p. 274, pl. 1, fig. 12 .

1994. Tmaegoceras lacordarei (Michelin, 1835). Guérin-Franiatte, pp. 166 ff., fig. 79 (re-illustration of Michelin 1835, pl. 67), pl. 30, fig. 11 (cast of lectotype).

?2007. Tmaegoceras gr. crassiceps Pompeckj, 1901. Géczy, Meister, pp. 168, pl. 13, figs. 3, 5, 10 .

2013. Tmaegoceras crassiceps Pompeckj. Howarth, p. 20, fig. $3.13 \mathrm{e}, \mathrm{f}$.

2014. Tmaegoceras crassiceps Pompeckj, 1901. Hou, pp. 91 ff., pl. 4 , figs. $1,2$.

2018. Tmaegoceras latesulcatus (v. Hauer). Schweigert, pl. 3, fig. 4.

2020. Tmaegoceras crassiceps Pompeckj. Scherzinger et al., p. 44.

2021. Tmaegoceras lacordairei (Michelin). Taylor, Guex, pp. $382 \mathrm{ff}$, figs. 23.1-23.8, 23.12, 23.13.

2021. Tmaegoceras lacordairei (Michelin). Meister et al., p. 210, figs. E-F.

Remarks. In literature, there exists a remarkable variation of spelling of this species name. Even when introduced into science, two different spellings appeared. In the description itself it is spelled "lacordarii", whereas in the list of taxa of the same journal's volume it is spelled "lacordairii". Subsequently, Koch (1909a, b) emended the name as "lacordairei", a procedure, however, which is not adopted by the current ICZN (1999). Which version is the correct name? According to Art. 32.3 of the ICZN (1999), the original spelling is the valid one, with only few clearly defined exceptions. As a common practise in the early $19^{\text {th }}$ century, the family name "Lacordaire" of the finder was latinized and became "Lacordarius". Consequently, the ammonite was named Ammonites lacordarii. The alternative version "lacordairii" in the list of taxa has not been compiled by Michelin himself, but by the editor of the book and must be regarded as an incorrect subsequent spelling. Thus, lacordarii is the correct name of the taxon.

The original specimen of Ammonites lacordarii described and illustrated from Lower Jurassic (Sinemurian) strata at Pouilly-en-Auxois (Côte-d'Or, France) could not be traced. Although Michelin (1835) described only a single specimen, he mentioned additional material in the de Boissy collection; therefore, at least two syntypes must have existed. The sole illustrated one from the Michelin collection, collected by Jean Philippe Lacordaire and previously considered to be the holotype, is here formally designated as the lectotype of Ammonites lacordarii. Koch (1909a, b) based his identification on the photograph of a plaster cast housed at the British Natural History Museum which had been provided to him by the curator George Charles Crick. Another plaster cast appeared in the collection of the Musée de Sémur (no. $471 \mathrm{AW}$ ) and was illustrated by Guérin-Franiatte (1994).

Description of new material. SMNS 70626/4, a steinkern from the 'Schneckenfels' of Balingen-Engstlatt, is the smallest of all specimens (Fig. 3G). There is no doubt that this specimen is a juvenile. A broad sulcus with a median keel is developed in all visible stages. However, the keel is developed as high as the margins of the venter. On the outermost part of the venter, remains of the shell are preserved. The growth lines are strongly curved forward towards the still unkeeled lateral margins of the sulcus. The suture lines are well discernible; they are not crowded and have a very simple style, with broad, densely serrated lobes and saddles (Fig. 4 top).

SMNS 70626/5, from the same locality and bed as SMNS 70626/4, is a medium-sized specimen of $51.5 \mathrm{~mm}$ diameter in steinkern preservation and with poor remains of the shell (Fig. 3H). The specimen is a phragmocone without body chamber. The flanks of one side and about one half of the venter are corroded. The other flank, however, is wellpreserved showing an extremely rursiradiate ribbing. The ribs appear along the umbilical edge and fade out before reaching the rounded ventrolateral shoulder. The innermost whorls have only a few weak, wide-spaced ribs. The broad ventral sulcus exhibits a low and narrow median keel and is clearly bordered by lateral keels.

SMNS 70626/3 from the collection of the private collector Alfred Hagenlocher $(\dagger)$ is a completely chambered nucleus in steinkern preservation (Fig. 3E, F). Its precise bed within the Arietenkalk Formation is not mentioned on the original label, but it originates from Reutlingen-Betzingen, 


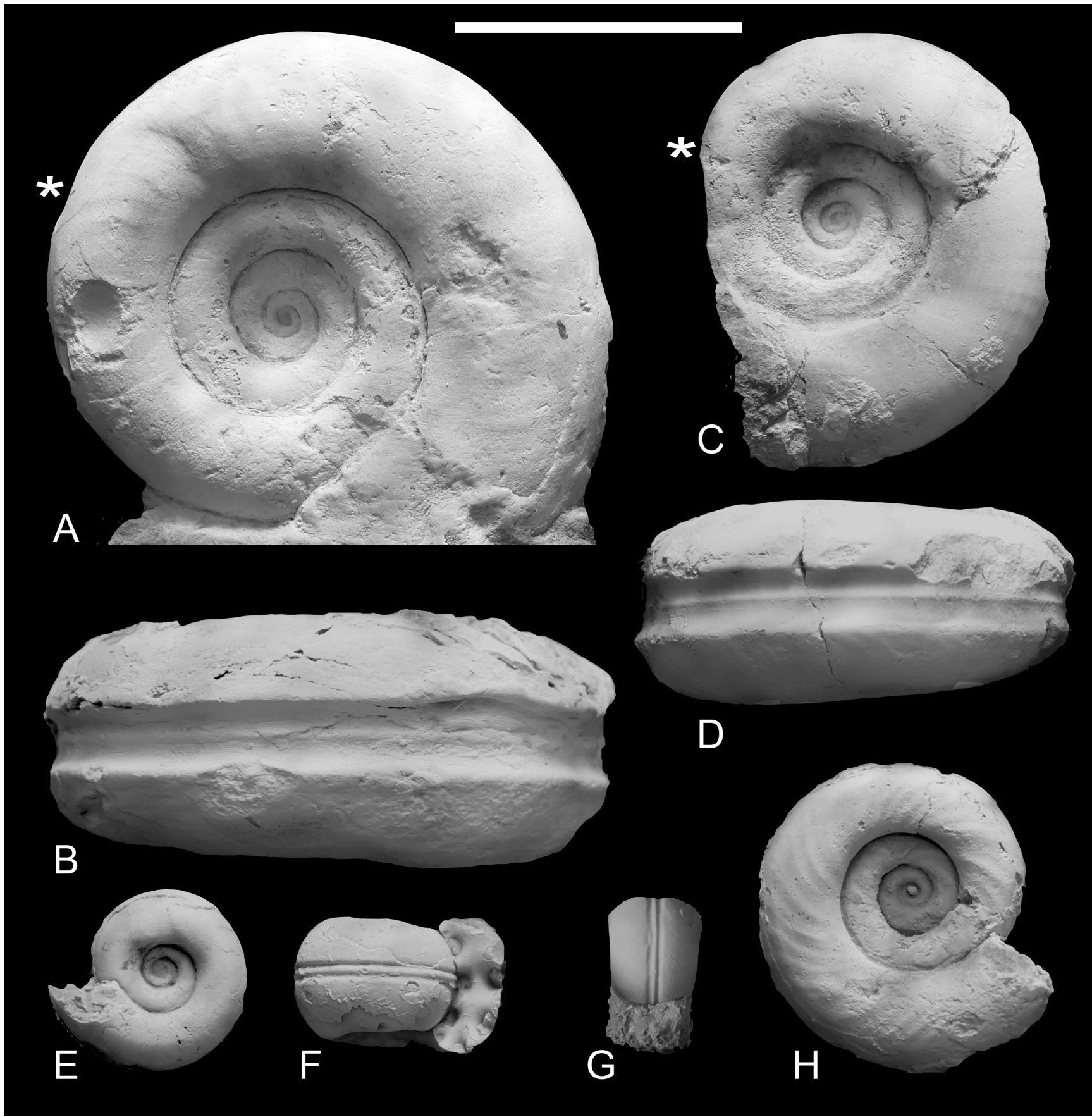

Fig. 3. Tmaegoceras lacordarii (Michelin, 1835). Arietenkalk Formation, Early Sinemurian, Bucklandi Zone, 'cf. pinguis' Biohorizon

A, B. SMNS 70626/1, Hechingen (collected by N. Wannenmacher); C, D. SMNS 70626/2, Reutlingen-Betzingen (collected by R. Flaig, donated by K. Jenne); E, F. SMNS 70626/3, Reutlingen-Betzingen (collected by A. Hagenlocher); G. SMNS 70626/4, Balingen-Engstlatt (collected by N. Wannenmacher); H. SMNS 70626/5, Balingen-Engstlatt (collected by N. Wannenmacher). Asterisk indicates end of phragmocone. Scale bar $=50 \mathrm{~mm}$

as the specimen described above. Some relics of the shell indicate that the shell has been either removed during preparation or remained on the counterpart when the surrounding rock was cut into smaller pieces. The whorl section is kidney-shaped, with the maximum width approximately at mid-flank. Both flanks lack any ornamentation except for 


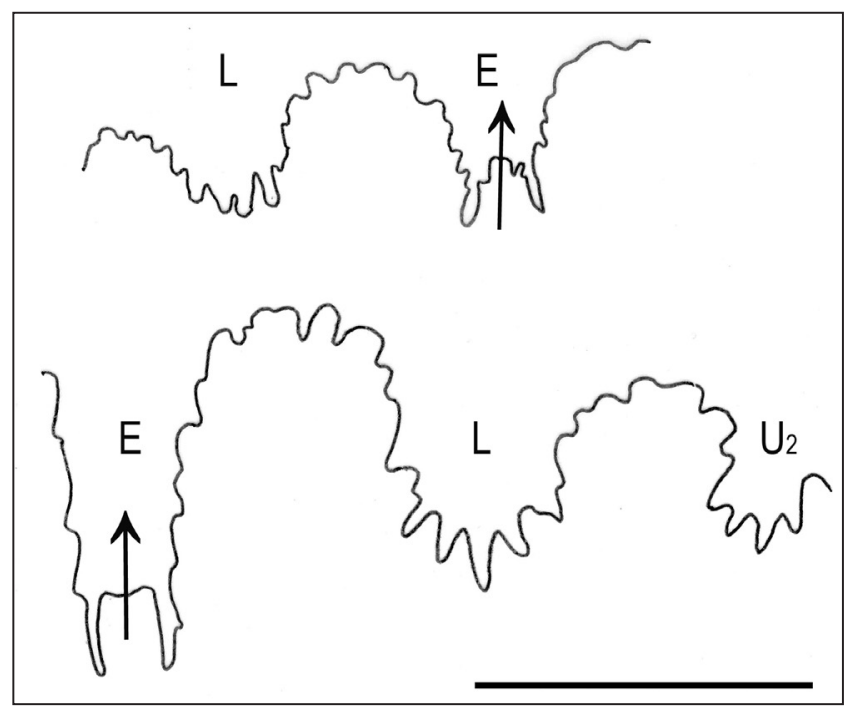

Fig. 4. Suture lines of Tmaegoceras lacordarii (Michelin, 1835)

$\mathrm{E}=$ external lobe, $\mathrm{L}=$ lateral lobe, $\mathrm{U}_{2}=$ umbilical lobe 2; arrows indicate direction of growth. Top: SMNS 70626/4, base: SMNS 70626/3. Scale bar = $50 \mathrm{~mm}$

a few weak, distantly spaced rursiradiate folds restricted to the inner half of the flanks of the outer whorl. Inner whorls are completely smooth. The ventral sulcus becomes gradually stronger during growth, and the median keel, which is equally high as the venter in the earliest visible stage, soon reaches a deeper position due to the deepening of the sulcus. The suture line is best preserved of all studied specimens (Fig. 4 base).

SMNS 70626/2 is a moderately large specimen (Fig. 3C, D) collected in 1989 by the private collector Robert Flaig $(\dagger)$ from a temporary outcrop of the Arietenkalk Formation in Reutlingen-Betzingen along the connecting road to Reutlingen-Degerschlacht. The exact limestone bed from which the specimen was obtained is unknown, but the matrix is biodetritic and well comparable with that of the specimens from the surroundings of Balingen and Hechingen thus suggesting its origination from an equivalent of the 'Schneckenfels'. Together with the smaller specimen described above, it represents the easternmost record of $T$. lacordarii in SW Germany. The almost smooth specimen was preserved with its shell, but most of the shell has been removed during preparation from the very hard rock matrix. The specimen shows a preadult stage, since there is no crowding of the last suture lines. The keeled ventral sulcus continues unchanged to the preserved end of the body chamber, which comprises a little less than half a whorl. In oblique illumination, a weak spiral striation is discernible on one flank of the steinkern of the body chamber; this charac- ter is not seen in any other compared specimen. Near the preserved end of the body chamber there is a shallow constriction-like depression followed by two weak, prorsiradiate ribs. These ribs present on the latest ontogenetic stage correspond well to the more numerous and stronger ones reported from the holotype of the monotypic Tmaegoceras paronai Bonarelli, 1899, hence suggesting the latter one was an adult specimen, despite of its smaller size. Bonarelli's specimen might represent a microconch, since it differs from adult $T$. lacordarii not only in its much smaller dimensions but also in a different whorl section closer to that of T. latesulcatum. Pompeckj (1901) speculated about a stratigraphic position of Tmaegoceras paronai within the Late Sinemurian Obtusum Zone, but this does not seem to be based on reliable grounds.

SMNS 70626/1, from the 'Schneckenfels' of Hechingen, is a large specimen with a diameter of $91.7 \mathrm{~mm}$ in steinkern preservation, with about half a whorl belonging to the body chamber (Fig. 3A, B). The position of the last chamber can be identified, but the suture lines cannot be followed at all. Since no crowding of the suture lines can be observed, it is unclear whether this large specimen was already adult or not. The keeled sulcate venter continues until the preserved end of the body chamber. The flank of the outer whorl is weakly ornamented with irregular rursiradiate growth lines running in the same style as the ribs in SMNS 20626/5.

A nicely preserved specimen from the 'Schneckenfels' of Bodelshausen stored in the private collection of Uwe Fidder (Reutlingen) could be studied only on the basis of photographs. Only one flank was prepared. On its inner whorls, a few very distant, extremely rursiradiate ribs are present. The growth lines are much lesser rursiradiate than these ribs and correspond to those observed in the other studied specimens. Due to the shell preservation, suture lines could not be observed.

The largest of all studied specimens is in the private collection of Thorsten Ott (Bisingen). It originates from the 'Schneckenfels' of Balingen-Engstlatt and is partly preserved with its shell (unfigured). A ribbing is not discernible, but the growth lines on the exposed flank run in a strongly rursiradiate style. The exact beginning of the body chamber could not be traced, but at least the last half of the outer whorl belongs to the body chamber.

Measurements. See Table 1.

Comparisons. Tmaegoceras lacordarii (Michelin, 1835) is distinguished from other species of Tmaegoceras by its relatively involute coiling and its great whorl width, which is reached early in ontogeny. Wide-spaced rursiradiate ribbing is present in juvenile stages and may persist into to medium ontogenetic stage. Deep dorsal sulcus with sharp median keel developed until the adult stage. 
Measurements of Tmaegoceras lacordarii (Michelin, 1835)

\begin{tabular}{|l|c|c|c|c|c|c|}
\hline \multicolumn{1}{|c|}{ Specimen } & $\mathrm{d}_{\max }[\mathrm{mm}]$ & $\mathrm{wh}[\mathrm{mm}]$ & $\mathrm{uw}[\mathrm{mm}]$ & $\mathrm{ww}[\mathrm{mm}]$ & $\mathrm{uw} / \mathrm{d}_{\max }$ & $\mathrm{ww} / \mathrm{d}_{\max }$ \\
\hline SMNS 70626/4 (Fig. 3G) & 17.7 & - & - & $(12)$ & - & 0.68 \\
\hline SMNS 70626/3 (Fig. 3E, F) & 26.3 & 8.8 & 9.2 & 16.8 & 0.35 & 0.64 \\
\hline SMNS 13181 & 29.0 & 11.5 & 9.0 & 19.0 & 0.31 & 0.66 \\
\hline Holotype T. crassiceps & 33.0 & 12.0 & 12.0 & 18.0 & 0.36 & 0.55 \\
\hline Unnumbered, priv. coll. U. Fidder & 50.0 & 18.5 & 18.5 & $(21)$ & 0.37 & $(0.42)$ \\
\hline SMNS 70626/5 (Fig. 3H) & 51.5 & 15.7 & 22.0 & $(31)$ & 0.43 & 0.60 \\
\hline SMNS 23153 & 59.0 & 19.0 & 28.5 & 32.0 & 0.48 & 0.54 \\
\hline SMNS 70626/2 (Fig. 3C, D) & 66.0 & 23.0 & 29.0 & 29.8 & 0.44 & 0.45 \\
\hline Lectotype T. lacordarii (cast) & 87.5 & 28.0 & 39.0 & 40.0 & 0.45 & 0.46 \\
\hline SMNS 70626/1 (Fig. 3A, B) & 91.7 & 26.4 & 40.3 & $(39)$ & 0.44 & 0.43 \\
\hline Unnumbered, priv. coll. T. Ott & 94.0 & 31.0 & 42.5 & - & 0.45 & - \\
\hline
\end{tabular}

\section{STRATIGRAPHIC POSITION AS EVIDENCED FROM THE NEW MATERIAL}

Gebhard, Schlatter (1977) provided a lithological section of the Arietenkalk Formation at Balingen-Engstlatt and indicated the occurrence of Tmaegoceras within a limestone bank (no. 7 in their section) known as the 'Schneckenfels' (Fig. 2). This stratigraphical position is principally that from which came all new finds of Tmaegoceras lacordarii from the same area. However, Gebhard, Schlatter (1977) provided a list of co-occurring ammonite taxa and placed the finding level biostratigraphically at the boundary between the Bucklandi and Semicostatum zones. Subsequently, Tmaegoceras was supposed to be indicative of the Semicostatum Zone (Braga et al., 1984; Böhm et al., 1999; Venturi et al., 2010). Meanwhile, however, a critical review of the succession of species of the ammonite genus Arietites in Southern Germany revealed that the Early Sinemurian Bucklandi Subzone terminates with the solarium Biohorizon, which is present in a thin limestone bed ('Uhrenfels' of Quenstedt, 1883) directly overlying the 'Schneckenfels' bed which contains the level with Tmaegoceras (Scherzinger et al., 2020). Apparently, the giant-sized Arietites solarium (Quenstedt, 1883) occurring in the top of Bed 8 of Gebhard, Schlatter (1977, fig. 1) was misidentified as Paracoroniceras charlesi Donovan, 1955, another large-sized species indicative of the basal Semicostatum Zone of the Upper Sinemurian.

As shown in our study, the occurrence of Tmaegoceras lacordarii is restricted in Southern Germany to a single biohorizon, provisionally termed as 'cf. pinguis' Biohorizon and belongs to the late Early Sinemurian Bucklandi Zone (Scherzinger et al., 2020). If correct, the ammonite taxa listed by Gebhard, Schlatter (1977) as co-occurring with Tmaegoceras in a Sinemurian section at Balingen-Endingen would point to a strong stratigraphic condensation of that bed. However, most of these taxa were misidentified: Arietites bucklandi (Sowerby, 1816) s. str. has never been recorded from the foreland of the Swabian Alb (Scherzinger et al., 2020), true Coroniceras rotiforme (J. de C. Sowerby, 1824) as well as Epammonites latisulcatus (Quenstedt, 1883) come from much deeper stratigraphical levels (Bloos, 2014), and Arnioceras falcaries (Quenstedt, 1856) as well as Arnioceras ceratitoides (Quenstedt, 1848) originate from significantly higher Lower Sinemurian beds. The most common ammonite accompanying Tmaegoceras lacordarii in the 'Schneckenfels' bed is the microconchiate Arnioceras subgeometricum Jaworski, 1931. Additional ammonite species identified by us are Arietites cf. pinguis (Quenstedt, 1883), Arietites costosum (Quenstedt, 1883) and Eucoroniceras sp. From the French type locality of Tmaegoceras lacordarii, Pouilly-en-Auxois in the Côte-d'Or, ammonite taxa ranging from the Bucklandi Zone till the Obtusus Zone were mentioned by Guérin-Franiatte (1966, pp. 64-65), but no topotype has appeared yet. In consequence of these data, the occurrence of Tmaegoceras lacordarii in the upper part of the North American Involutum Zone (Muellerense Subzone) of Nevada (Taylor, Guex, 2021) implies a correlation with the upper Bucklandi Zone (Bucklandi Subzone) of Europe and not with the lower part of the Semicostatum Zone (Lyra Subzone) as suggested therein.

\section{PHYLETIC RELATIONSHIPS AND ANCESTRY OF TMAEGOCERAS}

Previously, the rare Jurassic ammonite genus Tmaegoceras has been placed either in Arietitinae Hyatt, 1867 (Donovan, Forsey, 1973; Donovan et al., 1981; Venturi, Bilotta, 2008; Howarth, 2013) or in Alsatitinae Spath, 1924 
(Arkell, 1957; Schlegelmilch, 1976; Gebhard, Schlatter, 1977). In contrast, we here assign it to Pseudotropitinae Donovan in Donovan, Forsey, 1973, as a result of the following discussion.

When briefly discussing the possible phyletic relationships of the genus Tmaegoceras, Pompeckj (1901) mentioned Ammonites salinarius Hauer, 1846 as the only somewhat similar form known at that time. Indeed, when compared with Tmaegoceras latesulcatum (Hauer, 1856), Ammonites salinarius has an almost identical coiling and whorl section and it additionally shares the deep ventral sulcus with a relatively low and narrow median keel, and at least the adult body chamber becomes smooth. This was certainly an important observation that has been totally ignored by later authors. The holotype of Ammonites salinarius (Hauer, 1846: 30, pl. 10, figs. 1-3) was re-figured by Wähner (1886) in real size, but Wähner also illustrated a strikingly different ammonite, Ammonites euceras Gümbel, 1861, as a subjective junior synonym of the former. According to Wähner (1886), the illustration of the type specimen of $\mathrm{Am}$ - monites salinarius in his own monograph has some deficiencies and does not fully correspond to the original. This is why we tried to trace and illustrate the holotype photographically; however, unfortunately it could not be found in the collection of the Natural History Museum at Vienna and must be considered lost (A. Lukeneder, pers. comm. 2021). Since other available specimens of Hauer's monograph look very close to the drawings of his artist, we consider Hauer's original illustration (Fig. 5) to give a better impression of the species. Wähner's misleading interpretation of salinarius was adopted by Kment (2000), who assigned this taxon to Alpinoceras Lange, 1941. Later, Wähner (1891, p. 184, pl. 46, figs. 1, 2) introduced Arietites subsalinarius (Fig. 6), a species which exhibits a rursiradiate ribbing style on the flanks which recalls that of Hauer's original Ammonites salinarius. The deeply sulcate keeled venter is flattened as in Tmaegoceras and bears prorsiradiate biplicate secondaries in the inner whorls that emerge from strongly rursiradiate primaries. "Arietites" subsalinarius is a rare but characteristic ammonite in the basal Sinemurian of the Northern
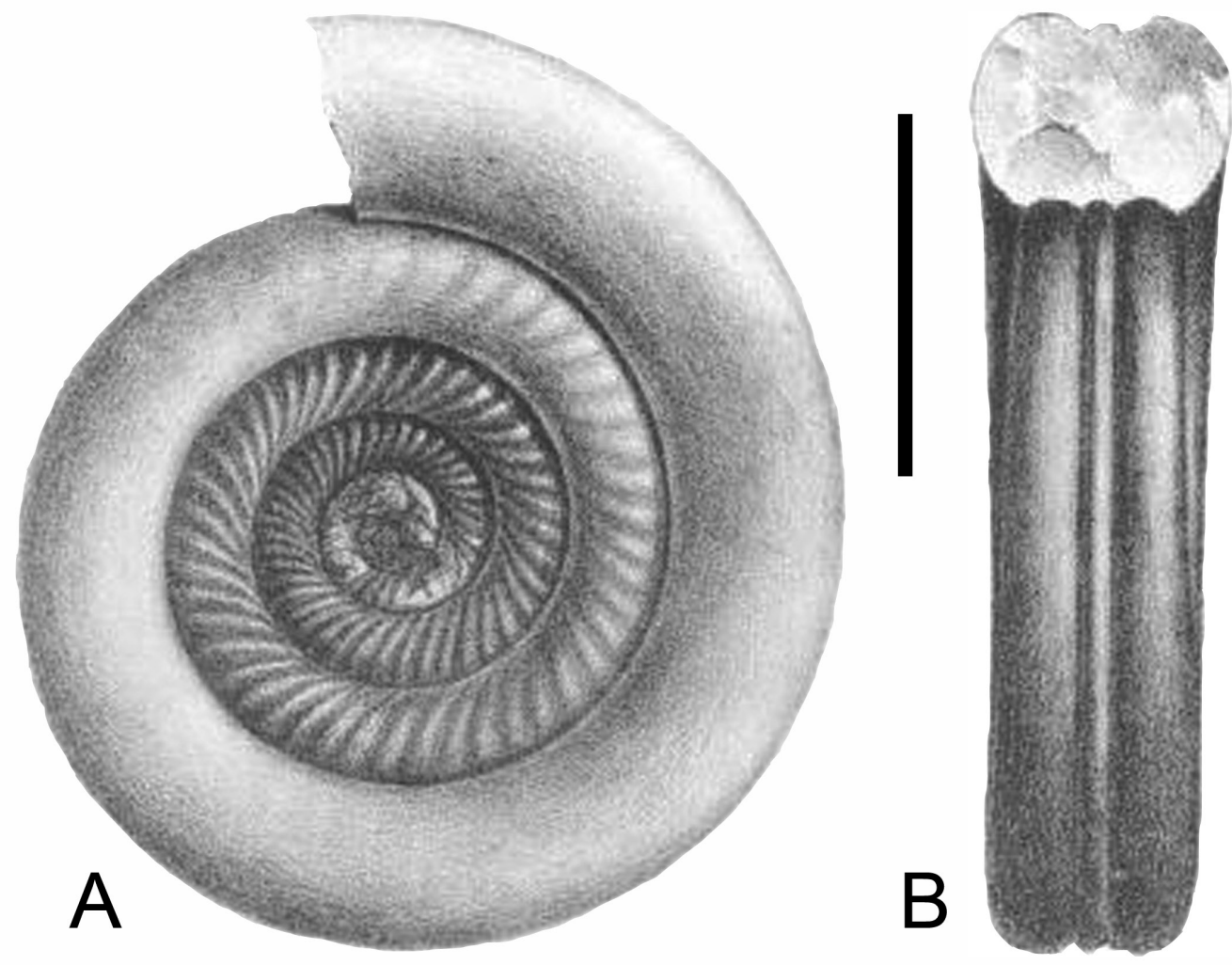

Fig. 5. Tmaegoceras salinarium (Hauer, 1846), holotype, from an unknown Austrian locality in the Northern Calcareous Alps (possibly from Adnet, according to Wähner 1886: p. 44). Illustration by Hauer (1846); original specimen could not be traced in the NHMW collection 


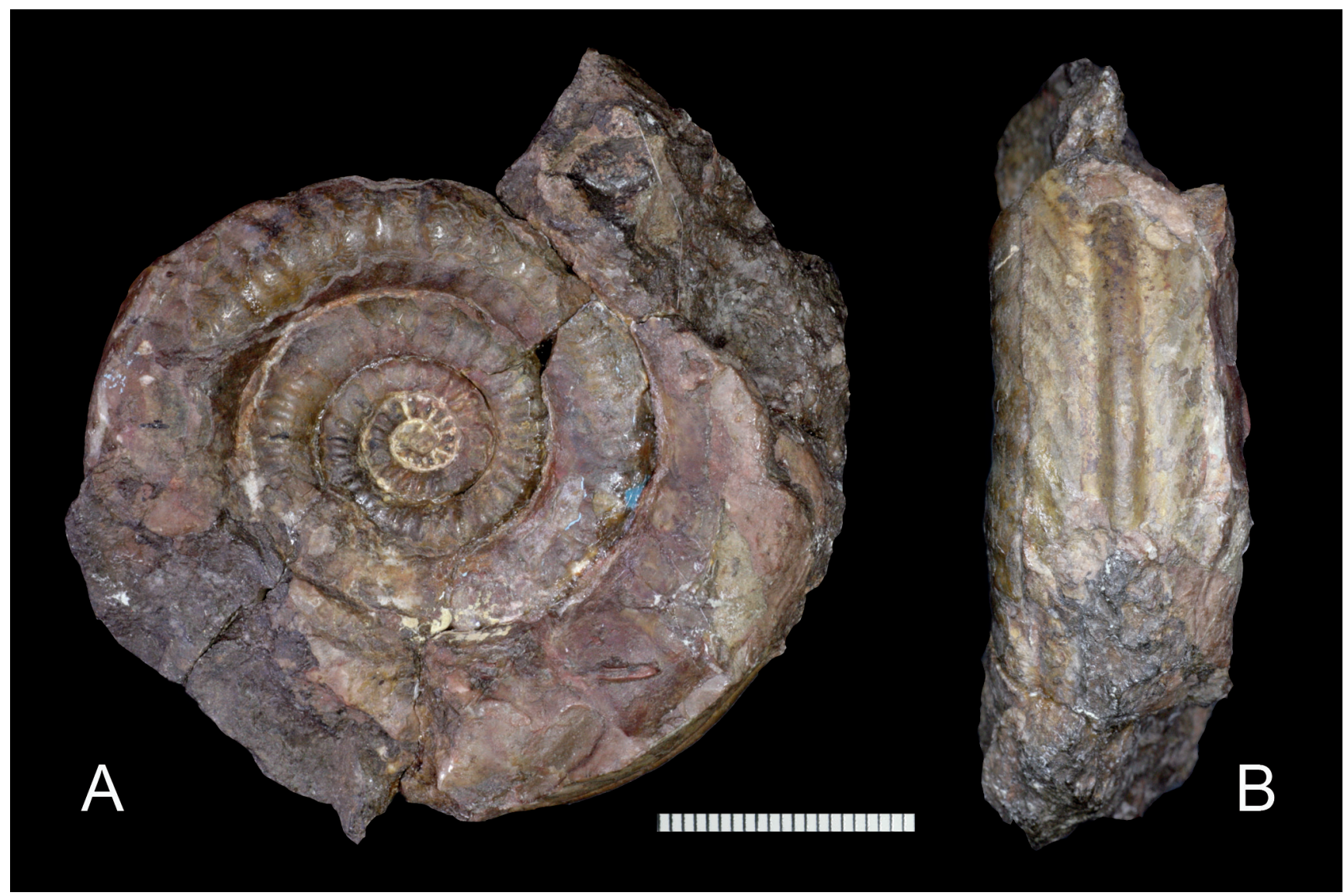

Fig. 6. “Arietites” subsalinarius Wähner, 1891, syntype. Original of Wähner, 1891, pl. 16, fig. 1, GBA 1891/002/0001

Scale bar $=20 \mathrm{~mm}$

Calcareous Alps (Kment, 2000, 2021). Specimens reported as "Paracaloceras subsalinarius" from Nevada (Taylor, 1990) do not show the typical rursiradiate ribbing in their early and median ontogenetic stages and have a more rounded venter; thus, they do not belong to this taxon. Possibly, they represent true Paracaloceras Spath, 1923, although the American specimens develop a keeled venter earlier in ontogeny than in the European type species of Paracaloceras (Howarth, 2013). Specimens reported from the Upper Hettangian of Chile such as "Paracaloceras cf. subsalinarius" (Hillebrandt, 2000, pl. 5, fig. 6) or "Laqueoceras (?)" (Hillebrandt, 2000, pl. 4, fig. 1), however, share the coarse, extreme rursiradiate ribbing style and a great whorl width, and the large-sized latter one became smooth already in a subadult stage. These poorly known Hettangian forms might represent phyletic forerunners of the true Ammonites salinarius. "Arietites" subsalinarius was already tentatively included in Pseudotropitinae by Donovan (in Donovan, Forsey, 1973) due to its characteristic ventral aspect, an opinion with which we concur. Unfortunately, we neither know the exact locality (possibly Adnet) nor the bed from which the supposedly lost holotype of Ammonites salinarius was collected. Morphologically, it looks like a perfect link between "Arietites" subsalinarius from the earliest Sinemurian (age of the latter after Kment, 2021) and Tmaegoceras lacordarii from the latest Early Sinemurian. Most strikingly, even the unique, extremely rursiradiate ribbing style of Ammonites salinarius and "Arietites" subsalinarius is shared with Tmaegoceras lacordarii, as it is clearly demonstrated from our new material. This strange ribbing style was already briefly noticed by Gebhard, Schlatter (1977), but since they did not express this observation in an easily understandable way and their illustrations hardly show this character, Howarth (2013) erroneously assumed that ribbing was completely absent in Tmaegoceras. However, an identical rursiradiate ribbing is also weakly discernible in the outer whorl of a Tmaegoceras lacordarii specimen from Nevada (Taylor, Guex, 2021, fig. 23.3). The prorsiradiate style of the secondaries present in "Arietites" subsalinarius as reported by Wähner (1891) appears in the adult stage of some 
Tmaegoceras. This makes it highly probable that the very peculiar ribbing style now recorded in some but not all Tmaegoceras specimens is an atavism indicative of the ancestors of this enigmatic genus.

Additionally, the suture line of the adult stage of the lectotype of Tmaegoceras latesulcatum (see Böhm et al., 1999, text-fig. 44) is quite similar to that of Ammonites salinarius, but less split. In the juvenile and median stage, however, the suture lines of Tmaegoceras still remain very simple; they have shallow and widely serrated lobes and saddles and a narrow external lobe (Fig. 4). These features resembles the suture lines of some Pseudotropitinae, namely that of "Arietites" ligusticus Cocchi in Canavari, 1882 (see Canavari, 1882, pl. 7, figs. 7-8), but also - even closer - that of some stratigraphically much younger (presumably homoeomorphic) Hildoceratoidea, such as the Toarcian genera Leukadiella Renz, 1913 (see Wendt, 1966), Cingolites Sassaroli, Venturi, 2010, or Urkutites Géczy, 1967 (see Sassaroli, Venturi, 2010, 2015). This observation might indicate a close correlation between conch shape and suture complexity, an assumption that hampers the often-supposed high taxonomical value of this character (see Schindewolf, 1962). Or is there a cryptic phyletic connection between these stratigraphically rather distant groups - an idea going back to Renz (1913)? At present, it is impossible to answer this question with confidence. Another outstanding question is whether Pseudotropitinae originate in early Arietitidae, or if their striking morphological resemblance to some Triassic Tropitidae Mojsisovics, 1875 is not simply homoeomorphic but phyletic in nature. Of course, the lack of any of such forms across the Triassic-Jurassic boundary makes a phyletic relationship between Triassic Tropitidae and Jurassic Pseudotropitinae rather unlikely. On the other hand, a small-sized Triassic tropitid ammonite with a very similar suture line and a morphology resembling that of Pseudotropites ultratriassicus has been illustrated from the late Carnian of Nepal as “Microtropites sp. indet." by Krystyn (1982, pl. 7, fig. 5). Buckman (1898) was the only one who rooted Tmaegoceras somewhere in the Late Triassic. His hypothesis was based on much less data than we have today, but it should be taken into consideration, since more ammonoid lineages than previously expected seem to have survived the Triassic-Jurassic mass extinction (e.g., Venturi, Bilotta 2008; Bilotta, 2010), and ammonite data from the Late Triassic and Hettangian are still scarce on a worldwide scale, mainly due to widespread hiatuses and/or diagenetically altered shallow-water lithologies unfavourable for ammonite preservation.

According to our present knowledge, Pseudotropitinae includes Pseudotropites Wähner, 1894, Canavarites Hyatt, 1900, and Tmaegoceras Hyatt, 1889 (Schweigert et al., 2011 and this study). The monotypic genus Claviceras Venturi, Nannarone, 2002, originally assigned to Pseudotropi- tinae as well, has been tentatively interpreted as a junior synonym of Euagassiceras Spath, 1924 (Howarth, 2013), however, without giving any reliable reason for such a placement. In respect of its clavate ribbing style it seems more likely that Claviceras is synonymous with Eucoroniceras Spath, 1922. The apparent co-occurrence of Pseudotropites ultratriasicus (Canavari, 1882) and "Arietites" subsalinarius Wähner, 1891 in the Early Sinemurian Lienbach Member of the Adnet Formation in Austria (K. Kment, pers. comm.) points to a possible sexual dimorphism between these two taxa, with the former being the microconchs and the latter the corresponding macroconchs. If this was the case, "Arietites" subsalinarius must be included in Pseudotropites, whereas Ammonites salinarius is safely assigned to Tmaegoceras.

Additional finds are needed to clarify the relationships among Pseudotropitinae and its phyletic roots either within very early arietitids or elsewhere. Having in mind the above mentioned South American records of salinarius/subsalinarius-like forms and the relatively great abundance of Tmaegoceras spp. in Nevada, an origination and phyletic hotspot of this exotic clade somewhere on the shelves of the Panthalassa Ocean appears very likely. Unfortunately, large parts of the potential distribution areas belonged to the Farallon Plate (Hawley, Allen, 2019), and much of their record is lost forever due to the almost complete subduction of that plate. The occasional spreading of Pseudotropitinae from the Panthalassa towards the western Tethys appeared much earlier before a closer marine connection between these oceans developed in the area of present-day Cuba and Mexico, known as the "Hispanic Corridor". Based on the distributions of some bivalve taxa, an opening of this "Hispanic Corridor" in the Hettangian or even in the Late Triassic has been repeatedly proposed (Damborenea, 1998; Sha, 2019). Although an opening of this seaway in the Pliensbachian as suggested by Aberhan (2001, 2002), based on a more expanded faunal analysis and palaeogeographic reconstructions (Scotese, 2014; Scotese, Schettino, 2017) appears more likely to us, at present, the true migration route of Tmaegoceras remains unclear.

Acknowledgements. Christine Deuringer (BisingenThanheim) kindly donated specimens from the collection of the late Norbert Wannenmacher. Volker Dietze (Nördlingen) is thanked for taking care of these specimens. Klaus Jenne (Bötzingen) donated another specimen originating from the collection of the late Robert Flaig. Martin Kapitzke (SMNS) is thanked for preparing the latter specimen. Uwe Fidder (Reutlingen) and Thorsten Ott (Bisingen) provided information on of their Tmaegoceras specimens. Irene Zorn (Geologische Bundesanstalt, Wien) kindly provided photos of the specimen illustrated in Fig. 5. Alexander Lukeneder 
(Natural History Museum Vienna) searched intensively but without success for a historical type specimen in the collection under his care. Finally, we wish to express our cordial thanks to Christian Meister (Genève) and József Pálfy (Budapest) for their thorough and helpful reviews, John Wright (London) for final linguistic improvements, and Paweł Zawada (Warsaw) for his professional editing. This paper is dedicated to the memory of our friend Norbert Wannenmacher (1961-2020).

\section{REFERENCES}

ABERHAN M., 2001 - Bivalve palaeobiogeography and the Hispanic Corridor: time of opening and effectiveness of a protoAtlantic seaway. Palaeogeography, Palaeoclimatology, Palaeoecology, 165: 375-394.

ABERHAN M., 2002 - Opening of the Hispanic Corridor and Early Jurassic bivalve biodiversity. Geological Society London, Special Publications, 194: 127-139.

ARKELL W.J., 1957 - Cephalopoda, Ammonoidea. In: Treatise on Invertebrate Palaeontology, Part L, Mollusca, 4 (Ed. R.C. Moore): L80-L490; The University of Kansas Press, Lawrence.

BILOTTA M., 2010 - Aequiloboidea: A new Early Jurassic ammonite superfamily of the Mediterranean Tethys. Geobios, 43, 6: 581-604.

BLOOS G., 2014 - On Ammonites silvestrei Reynès - a significant element of the Arietitinae in the Lower Jurassic (Lower Sinemurian, Bucklandi Zone, Rotiforme Subzone) of the NW European Province. Neues Jahrbuch für Geologie und Paläontologie, Abhandlungen, 274, 2/3: 255-270.

BLOOS G., DIETL G., SCHWEIGERT G., 2006 - Der Jura von Süddeutschland in der Stratigraphischen Tabelle von Deutschland 2002. Newsletters on Stratigraphy, 41: 263-277.

BÖHM F., EBLI O., KRYSTYN L., LOBITZER H., RAKÚS M., SIBLIK M., 1999 - Fauna, stratigraphy and depositional environment of the Hettangian-Sinemurian (Early Jurassic) of Adnet (Salzburg, Austria). Abhandlungen der Geologischen Bundesanstalt, 56: 143-271.

BONARELLI G., 1899 - Cefalopodi Sinemuriani dell'Appennino Centrale. Palaeontographia Italica, 5: 55-83.

BRAGA J.-C., MARTIN-ALGARRA A., RIVAS P., 1984 - Hettangian and Sinemurian of Baños de Alhama de Granada reference section for the Westmediterranean Hettangian (Betic Cordillera, Southern Spain). Geobios, 17, 3: 269-279.

BUCKMAN S.S., 1898 - On the grouping of some divisions of socalled "Jurassic Time". Quarterly Journal of the Geological Society, 54: 442-462.

CANAVARI M., 1882 - Beiträge zur Fauna des unteren Lias von Spezia. Palaeontographica, 29: 125-192.

CORNA M., 1987 - Les horizons sinémurian du Calcaires à gryphées du Jura méridional français (zone à Conybeari - zone à Obtusum). Géobios, 20: 531-536.

CORNA M., DOMMERGUE J.-L., MEISTER C., MOUTERDE R. 1997 - Sinémurien. In: Biostratigraphie du Jurassique ouesteuropéen et méditerranéen (eds. É. Cariou, P. Hantzpergue).
Bulletin du Centre de Recherche Elf Exploration et Production, Mémoires, 17: 9-14.

CRICK C.G., 1902 - Note on the genus Tmaegoceras, Hyatt. Geological Magazine, 9: 127-128.

DAMBORENEA S., 1998 - Hispanic Corridor: Its evolution and the biogeography of bivalve molluscs. GeoResearch Forum, 6: 369-380.

DOMMERGUES J.-L., MEISTER C., 2017 - Ammonites du Jurassique inférieur (Hettangien, Sinémurien, Pliensbachien) d'Afrique du Nord (Algérie, Maroc et Tunisie). Atlas d'identifications des espèces. Revue de Palóbiologie, 36, 2: 189-367.

DONOVAN D.T., 1955 - Révision des espèces décrites dans la «Monographie des Ammonites» (Lias inférieur) de P. Reynès. Mémoire de la Société géologique de France, nouvelle série, 73: $1-45$.

DONOVAN D.T., FORSEY G.F., 1973 - Systematics of Lower Liassic Ammonitina. The University of Kansas Paleontological Contributions, 64: 1-18.

DONOVAN D.T., CALLOMON J.H., HOWARTH M.K., 1981 Classification of Jurassic Ammonitina. In: The Ammonoidea (eds. M.R. House, J.R. Senior). Systematic Association, Special Volumes, 18: 101-155.

FISCHER P.H., 1882 - Manuel de conchyliologie et de paléontologie conchyliologique. Savy, Paris.

FÜLÖP J., 1976 - The Mesozoic basement Horst blocks of Tata. Geologica Hungarica, Series Geologica, 16: 2-229.

GEBHARD G., SCHLATTER R., 1977 - Über das Vorkommen von Tmaegoceras Hyatt (Ammonoidea) im Lias Europas. Stuttgarter Beiträge zur Naturkunde, Serie B, 22: 1-15.

GÉCZY B., 1967 - Upper Liassic ammonites from Úrkút, Bakony Mountains, Transdanubia, Hungary. Annales Universitatis Scientiarum Budapestinensis de Rolando Eötvös nominatae, Sectio Geologica, 10: 115-160.

GÉCZY B., MEISTER C., 2007 - Les ammonites du Sinémurien et du Pliensbachien inférieur de la montagne du Bakony (Hongrie). Revue de Paléobiologie, 26, 1: 137-305.

GEYER G., 1886 - Über die liasischen Cephalopoden des Hierlatz bei Hallstatt. Abhandlungen der kaiserlich-königlichen geologischen Reichsanstalt, 12: 213-286.

GUÉRIN-FRANIATTE S., 1966 - Ammonites du Lias inférieur de France, Psilocerataceae, Arietitidae. Centre National de la Recherche Scientifique, Paris.

GUÉRIN-FRANIATTE S., 1990 - Ammonites du Lias inférieur de France (II): Psiloceratidae, Schlotheimiidae et premiers Arietitidae. Mémoires du Centre d'études et de recherches géologiques et hydrologiques, 29: 1-207.

GUÉRIN-FRANIATTE S., 1994 - Biostratigraphie et paléobiogéographie des ammonites. Une synthèse pour le Lias inférieur de France. Géobios, Mémoire spéciale, 17: 265-273.

GUEX J., 1981 - Quelques cas de dimorphisme chez les ammonïodés du Lias inférieur. Bulletin de la Société Vaudoise des Sciences Naturelles, 75: 239-248.

GUGENBERGER O., 1936 - Zur Kenntnis einiger unbekannter Arten aus dem Unterlias (Bucklandi-Zone) der Provinz Palermo. Sitzungsberichte der Akademie der Wissenschaften, mathematisch-naturwissenschaftliche Klasse, 145: 48-58. 
GÜMBEL C.W., 1861 - Geognostische Beschreibung des bayerischen Alpengebirges und seines Vorlandes. Perthes, Gotha.

HAUER F. von, 1846 - Die Cephalopoden des Salzkammergutes aus der Sammlung Seiner Durchlaucht des Fürsten von Metternich. Ein Beitrag zur Paläontologie der Alpen. Verlag Braumüller und Seidel, Wien.

HAUER F. von, 1856 - Über die Cephalopoden aus dem Lias der nordöstlichen Alpen. Denkschriften der Kaiserlichen Akademie der Wissenschaften, mathematisch-naturwissenschaftliche Classe, 11: $1-86$.

HAWLEY W.B., ALLEN R.M., 2019 - The fragmented death of the Farallon plate. Geophysical Research Letters, 46: 7386-7394.

HENGSBACH R., 1986 - Über Ammonites dorsosulcatus Quenstedt 1884. Senckenbergiana lethaea, 67, 1/4: 331-336.

HILLEBRANDT A. von, 2000 - Die Ammoniten-Fauna des südamerikanischen Hettangium (basaler Jura). Teil III. Palaeontographica, Abteilung A, 258: 65-116.

HOU P., 2014 - Sinemurian (Early Jurassic) stratigraphy at Last Creek, British Columbia and Five Card Draw, Nevada: paleontology and environmental implications [Master of Science Thesis]. University of British Columbia, Vancouver.

HOWARTH M.K., 2013 - Part L, Revised, Volume 3B, Chapter 4: Psiloceratoidea, Eodoceratoidea [sic], Hildoceratoidea. Treatise Online, 57: 1-139.

HYATT A., 1867 - The fossil Cephalopoda of the Museum of Comparative Zoology. Bulletin of the Museum of Comparative Zoology, 5: 71-102.

HYATT A., 1889 - Genesis of the Arietitidae. Smithsonian Contribution to Knowledge, 673.

HYATT A., 1900 - Cephalopoda. In: Textbook of palaeontology (Ed. K.A. von Zittel), 1, 2: 502-592; Macmillan, London.

ICZN, 1999 - International Code of Zoological Nomenclature, $4^{\text {th }}$ Edition. The International Trust for Zoological Nomenclature, London.

JAWORSKI E., 1931 - Über Arnioceras geometricum Oppel und verwandte Spezies; nebst einem Anhang über Ammonites natrix Schlotheim. Neues Jahrbuch für Mineralogie, Geologie und Paläontologie, 65: 83-140.

KMENT K., 2000 - Frühe liassische Ammoniten aus der Gegend um Hinterriß im Karwendelgebirge (Tirol) und aus dem Mangfallgebirge bei Rottach-Egern (Bayern). Jahrbuch der Geologischen Bundesanstalt, 142: 181-218.

KMENT K., 2021 - Biostratigraphy of the Hettangian Stage in the Northern Calcareous Alps (Austria, Bavaria) with ammonoids and their classification into biohorizons. Neues Jahrbuch für Geologie und Paläontologie, Abhandlungen, 301, 3: 233-282.

KOCH [N.]F., 1909a-Adadok a „Tmaegoceras” nem ismeretéhez. Földtani Közlöny, 39: 275-280 [in Hungarian].

KOCH F., 1909b - Beiträge zur Kenntnis der Gattung Tmaegoceras. Földtani Közlöny, 39: 308-313 [German translation of Koch, 1909a].

KOVÁCS L., 1942 - Monographie der liassischen Ammoniten des nördlichen Bakony. Geologica Hungarica, Series Paleontologica, 17: 1-220.

KRYSTYN L., 1982 - Obertriassische Ammonoideen aus dem Zentralnepalesischen Himalaya (Gebiet von Jomsom). Abhandlungen der geologischen Bundesanstalt, 36: 1-63.
LAMARCK J.B.P.A. de, 1801 - Systême des animaux sans vertèbres. Déterville, Paris.

LANGE W., 1941 - Die Ammonitenfauna der Psiloceras-Stufe Norddeutschlands. Palaeontographica, Abteilung A, 93: 1-192.

MEISTER C., NEIGE P., DOMMERGUES J.-L., 2021 - Ammonites du Jurassiques. In: Muséum national d'Histoire naturelle, Paris, Collection stratotypes (eds. P. Neige, J.-L. Dommergues): 160-217.

MICHELIN H., 1835 - A. de Lacordaire. A. Lacordarii [sic]. Michelin. Magasin de Zoologie, 5, 5: pl. 67.

MOJSISOVICS E. von, 1875 - Das Gebirge um Hallstatt I. 2. Abhandlungen der kaiserlich-königlichen Geologischen Reichsanstalt, 6, 1: 83-174.

MOJSISOVICS E. von, 1893 - Die Cephalopoden der Hallstätter Kalke. 2. Abhandlungen der kaiserlich-königlichen geologischen Reichsanstalt, 6, 2: 1-835.

MOUTERDE R., CORNA M., OLIVIER P., MOURIER T., 1986 - Ammonites d'affinités mésogéenne dans le Lias inférieur des blocks prédorsalien du Rif (Maroc). In: PICGUNESCO 183 Marrakech 1985. Revue de la Faculté des Sciences de Marrakech, Section Sciences de la Terre, Numéro spécial, 2: 349 367.

PAGE K.N., 2003 - The Lower Jurassic of Europe: its subdivision and correlation. Geological Survey of Denmark and Greenland Bulletin, 1: 23-59.

PAGE K.N., 2010 - Stratigraphical framework. In: Fossils from the Lower Lias of the Dorset Coast (eds. A.R. Lord, P.G. Davies): 33-53. The Palaeontological Association, London.

POMPECKJ J.F., 1901 - Über Tmaegoceras Hyatt. Neues Jahrbuch für Mineralogie, Geologie und Paläontologie, 1901: 158-170.

QUENSTEDT F.A., 1845-1849 - Petrefaktenkunde Deutschlands. 1. Abt. Vol. 1. Cephalopoden. [pp. 1-104 (1845); pp. 105-184 (1846); pp. 185-264 (1847); pp. 265-472 (1848); pp. 473-580 (1849)]. Fues Verlag, Tübingen.

QUENSTEDT F.A., 1856-1857 - Der Jura. Laupp'sche Verlagsbuchhandlung, Tübingen.

QUENSTEDT F.A., 1882-1885 - Die Ammoniten des Schwäbischen Jura, 1, Der Schwarze Jura. Schweizerbart'sche Verlagsbuchhandlung, Stuttgart.

RENZ C., 1913 - Neue Arten aus dem hellenischen Jura und aus der indischen Dyas. 1. Neue Arten aus dem griechisch epirotischen Oberlias und Unterdogger. Zeitschrift der Deutschen Geologischen Gesellschaft, 64: 583-617.

REYNÈS P., 1879 - Monographie des Ammonites, 1re partie Lias. Baillère, Marseille and Paris.

SASSAROLI S., VENTURI F., 2010 - Cingolites n. gen., a new lower Toarcian Hildoceratinae (Ammonitina) from the Marchean Apennines (Cingoli, Macerata, Italy). Bollettino della Società Paleontologica Italiana, 49, 2: 97-118.

SASSAROLI S., VENTURI F., 2015 - Occurrence of the Toarcian genus Urkutites Géczy (Ammonitina, Hildoceratinae) in the Apennines (Italy). Hantkeniana, 10: 41-54.

SCHAFHÄUTL K.E., 1851 - Geognostische Untersuchungen des südbayerischen Alpengebirges. Literarisch-artistische Anstalt, München.

SCHERZINGER A., GRÄBENSTEIN S., SCHWEIGERT G., 2020 - Arietites solarium (Quenstedt, 1883) - a diagnostic 
ammonite in the Lower Jurassic (Early Sinemurian, Bucklandi Zone) of SW Germany. Volumina Jurassica, 18, 1: 37-46.

SCHINDEWOLF O.H., 1962 - Studien zur Stammesgeschichte der Ammoniten. Lieferung 2 (Ammonitina: Psilocerataceae, Eoderocerataceae). Abhandlungen der Mainzer Akademie der Wissenschaften und Literatur. mathematisch-naturwissenschaftliche Klasse, 8: 425-571.

SCHLEGELMILCH R., 1976 - Die Ammoniten des süddeutschen Lias. G. Fischer Verlag, Stuttgart and New York [2 $2^{\text {nd }}$ edition published 1992].

SCHWEIGERT G., 2018 - Jura-Ammoniten. Fossilien, Sonderhefte, 2018: 1-72.

SCHWEIGERT G., KAPITZKE M., SCHREIBER D., 2011 - First record of the Tethyan ammonite genus Canavarites Hyatt in the Lower Sinemurian of Germany, with description of a new species. Palaeodiversity, 4: 7-11.

SCOTESE C.R., 2014 - Atlas of Jurassic Paleogeographic Maps, PALEOMAP Atlas for ArcGIS, volume 3, The Jurassic and Triassic, Maps 32-42, Mollweide Projection, PALEOMAP Project, Evanston, IL. 10.13140/2.1.4850.4321.

SCOTESE C.R., SCHETTINO, A., 2017 - Chapter 3 - Late Permian-Early Jurassic Paleogeography of Western Tethys and the World. In: Permo-Triassic Salt Provinces of Europe, North Africa and the Atlantic Margins (eds. J.I. Soto et al.): 57-95; Elsevier, Amsterdam.

SHA J., 2019 - Opening time of the Hispanic Corridor and migration patterns of pan-tropical cosmopolitan Jurassic pectinid and ostreid bivalves. Palaeogeography, Palaeoclimatology, Palaeoecology, 515: 34-46.

SOWERBY J., 1815-1818 - The mineral conchology of Great Britain. Published by the author, London.

SOWERBY J. de C., 1824 - The mineral conchology of Great Britain, Volume 5, Parts 77-78: 338-648; Meredith, London.

SPATH L.F., 1922 - On Lower Lias ammonites from Skye. Geological Magazine, 59: 170-176.

SPATH L.F., 1923 - Shales-with-'Beef,' a sequence in the Lower Lias of the Dorset Coast. Part II: Palaeontology: The ammonites of the Shales-with-'Beef.' Quarterly Journal of the Geological Society of London, 79, 1: 66-88.

SPATH L.F., 1924 - The ammonites of the Blue Lias. Proceedings of the Geologists' Association, 35: 186-211.

SPATH L.F., 1925 - Notes on Yorkshire ammonites. The Naturalist, 1925: 359-364.

STEVENS G.R., 2004 - Hettangian-Sinemurian (Early Jurassic) ammonites of New Zealand. Monographs of the Institute of Geological and Nuclear Sciences, Wellington, New Zealand, 23: 1-107.

TAYLOR D.G., 1990 - Two species of Paracaloceras from Canadense Zone (Hettangian - Sinemurian stages) in Nevada (USA). Bulletin de la Société Vaudoise des Sciences Naturelles, 80, 2: 211-219.
TAYLOR D.G., 1998 - Late Hettangian-Early Sinemurian (Jurassic) ammonite biochronology of the western Cordillera, United States. Geobios, 31: 467-497.

TAYLOR D.G., GUEX J., 2021 - Early Sinemurian ammonoids and biochronology of the Sunrise Formation, New York Canyon, Mineral County, Nevada. New Mexico Museum of Natural History and Science Bulletin, 82: 371-391.

TAYLOR D.G., GUEX J., RAKUS M., 2001 - Hettangian and Sinemurian ammonoid zonation for the Western Cordillera of North America. Bulletin de la Société Vaudoise des Sciences Naturelles, 87, 4: 381-421.

URLICHS M., 1977 - The Lower Jurassic in Southwestern Germany. Stuttgarter Beiträge zur Naturkunde, Serie B, 24: 1-41.

VENTURI F., BILOTTA M., 2008 - New data and hypotheses on Early Jurassic ammonite phylogeny. Revue de Paleobiologie, 27: 859-901.

VENTURI F., NANNARONE C., 2002 - Ammonites of Lower Sinemurian in the M. Cetona (Siena, Italy). Bollettino della Societa Paleontologica Italiana, 41: 131-162.

VENTURI F., REA F., SILVESTRINI G., BILOTTA M., 2010 Ammoniti. Un viaggio geologico nelle montagne appenniniche. Porzi, Perugia.

WÄHNER F., 1886 - Beiträge zur Kenntnis der tieferen Zonen des unteren Lias in den nordöstlichen Alpen. IV. Teil. Beiträge zur Geologie und Paläontologie Österreich-Ungarns und des Orients, 5, 3: 37-74.

WÄHNER F., 1891 - Beiträge zur Kenntnis der tieferen Zonen des unteren Lias in den nordöstlichen Alpen. VI. Teil. Beiträge zur Geologie und Paläontologie Österreich-Ungarns und des Orients, 8, 4: 241-268.

WÄHNER F., 1894 - Beiträge zur Kenntnis der tieferen Zonen des unteren Lias in den nordöstlichen Alpen. VII. Teil. Beiträge zur Geologie und Paläontologie Österreich-Ungarns und des Orients, 9, 1: 1-54.

WALLISER O.H., 1956a - Chronologie des Lias alpha zwischen Fildern und Klettgau (Arietenschichten, SW-Deutschland). Neues Jahrbuch für Geologie und Paläontologie, Abhandlungen, 103: 181-222.

WALLISER O.H., 1956b - Stratigraphie des Lias alpha zwischen Fildern und Klettgau (Arietenschichten, SW-Deutschland). Neues Jahrbuch für Geologie und Paläontologie, Abhandlungen, 103: 281-311.

WANG Y., HE G., 1981 - Some Early Jurassic ammonoids from Eastern Himalayas. In: (ed. The scientific expedition team of the Chinese Academy of Sciences): Scientific expedition to the Qinghai-Xizang (Tibet) Plateau Series. Paleontology of Xizang, 3: 314-334; Science Press, Peking [in Chinese].

WENDT J., 1966 - Revision der Ammoniten-Gattung Leukadiella Renz aus dem mediterranen Oberlias. Neues Jahrbuch für Geologie und Paläontologie, Abhandlungen, 125: 136-154. 